\title{
THE EFFECT OF ADMINISTERING RHIZOME EXTRACT OF CURCUMA (Curcuma Xanthorrhiza Roxb.) AT VARIOUS DOSES ON THE THICKNESS OF VAGINAL EPITHELIUM IN MICE (Mus Musculus) EXPOSED TO MSG
}

\author{
Ria Ramadhani Dwi Atmaja \\ Department of Pharmacy Faculty of Medicine and Health Sciences Universitas Islam Negeri \\ Maulana Malik Ibrahim Malang
}

Corresponding author: ria.ramadhani85@yahoo.com

\begin{abstract}
The usage of Monosodium Glutamate (MSG) as flavour enhancer in food is increasing and has reached alarming condition. Excessive consumption of MSG results in the formation of a number of free radicals in the body and affects the function of hypothalamus. A disturbed hypothalamus results in the decline of estrogen levels, and in turn, this estrogen deficiency causes a decrease in vaginal epithelial proliferation in which epithelial cells become thinner. Giving antioxidants might help to address these problems. One of the plants that is rich in antioxidant and grow in mass in Indonesia is curcuma. This study is aimed at analyzing the effect of giving curcuma extract (Curcuma Xanthorrhiza Roxb.) with varying doses on the thickness of vaginal epithelium in mice that are exposed to MSG. The research design employed in the study is true experimental posttest only control group by using 5 groups, namely: $K 1$ (CMC-Na), K2 (MSG), P1 (MSG + curcuma rhizome extract dose of $0,4 \mathrm{mg} / \mathrm{gr}$ $B W), P 2$ (MSG + curcuma rhizome extract dose of 0,8mg/gr BW), P3 (MSG + curcuma rhizome extract dose of $1,2 \mathrm{mg} / \mathrm{gr} B W$ ). Vagina of each mouse was taken and studied to measure its epithelial thickness by using a $40 x$ magnification on Olympus micrograph microscope. Data were then analyzed using One Way ANOVA. The results show that there is no significant difference in the thickness of vaginal epithelium in each treatment ( $\rho$-value 0.341). Therefore, it can be concluded that the extract of curcuma rhizome does not have a significant influence on the thickness of vaginal epithelium in mice that are exposed to MSG.
\end{abstract}

Keywords : MSG, Curcuma Xanthorrhiza, epithelium, vagina.

\section{INTRODUCTION}

Monosodium glutamate (MSG) is sodium salt of L-glutamic acid, which is used as a flavor enhancer in food to stimulate appetite. MSG is the result of glutamate purification or a combination of some amino acids with a small amount of peptides resulted from the hydrolyzed vegetable protein/HVP. Glutamic acid is classified as a non-essential amino acid since human body can produce glutamic acid for itself. However, it is an essential element of protein that can be found in vegetables, meat, fish and breast milk (Septadina, 2014). Spectacular breakthrough that is currently being developed is producing monosodium glutamate synthetically. This synthetic monosodium glutamate is what triggers the massive use of food enhancer at any level, especially in food industries. The maximum dose of MSG that can serve its function as flavour enhancer is $60 \mathrm{mg} / \mathrm{kg}$ (Giacometti, 1979).

The use of MSG worldwide has been growing rapidly in recent years. Almost all food products including fast food and packaged food contain flavor enhancer (MSG). MSG consumption spreads throughout the world, including Indonesia. In fact, in 2009 the consumption of MSG was mostly found in Asia which accounted for approximately $91 \%$ of the production of MSG in the world. In addition to China, Indonesia was one of primary MSG 
producers in Asia and it was expected that the production would rise during 2009-2014. Based on a health research data in 2007 , MSG was consumed by $77.8 \%$ of the population of Indonesia (Ministry of Health of Indonesia, 2008)

In 1968, Robert Ho Man Kwok reported in the New England Journal of Medicine about a Chinese restaurant syndrome which included symptoms such as burnt sensation, prickling sensation on face and neck, chest tightness and so on. Kaemmerer (1999) suggested that some sensitivity reactions that might occur because of monosodium glutamate are headaches, migraines, cramps, nausea, vomiting, palpitations, shortness of breath and rashes on skin (Walker \& Lupien, 2000). In addition, some other researchers stated that MSG can cause endocrinal interference through the mechanism of hypothalamic-hypophysis.

Camihort et al (2005) reported that MSG is neurotoxic in nature and can cause ablation of the arcuate nucleus of the hypothalamus which can disrupt the function of the hypothalamic-pituitary-organ target. The hypothalamus secretes gonadotropin releasing hormone which in turn stimulates secretion of folicle stimulating hormone (FSH) and luteinizing hormone (LH) from the anterior pituitary. Both of these hormones are necessary for sex cells development in women and because both are significant for the process of oogenesis and spermatogenesis. Interference on hypothalamic function results in the disruption of endocrine functions, including reproductive hormones that in the end affect the function of gonads.

Other research was conducted by Redding T (1971) which revealed that administration of MSG can reduce the levels of GnRH and LH in anterior pituitary gland. In the study conducted by Lamperti et al (1976), it was revealed that MSG causes lesions at hypothalamic arcuate nucleus in mice that lead to some changes in the reproductive system, including inhibition of follicle development in the ovary. In the following year, Lamperti (1977) again conducted an experiment showing that MSG can reduce stimulant response towards gonadotropin-releasing hormone $(\mathrm{GnRH})$ which results in the decline of FSH and LH levels in blood plasma (Stehle, 2007), and of course the decrease of FSH and LH level causes drop in estrogen and progesterone level.

Other research also shows the effect of MSG on reproductive organs. For example, a study conducted by Trentini (1990) showed that when both female and male mice were given MSG, there was a decrease in the weight of endocrine glands, as in the pituitary gland, thyroid, ovary, and testis. Once mature, the female mice that were given MSG experienced delay in vaginal canalization and had longer estrous cycle than those from control group. The effect of MSG on estrous cycle in rats was also reported by Megawati, Sutarno and Listyawati (2005) which stated that based on vaginal smear results, MSG administration generally shortened diestrus phase, but extended proestrus and estrus phases. Meanwhile, the effect of MSG on the thickness of vaginal epithelium has not been studied yet, while in fact there is a possibility of influence by MSG on sex organ considering that vagina also has estrogen receptors. A decline in vaginal estrogen levels will cause a decrease in epithelial proliferation, and epithelial maturation becomes intermediate and superficial cells. This happens because all layers disappear, except basal cell layer. The epithelium of the vagina becomes pale and very thin and thus susceptible to infections and inflammatory submucosal tissue, causing local irritation and tend to cause bleeding.

Farombi and Onyema (2006) reported that administration of 4mg MSG in each gram of body weight (equivalent to $30-40 \mathrm{mg} / \mathrm{kg}$ in humans) peritoneally can cause oxidative stress that can lead to reactive oxygen species (ROS). Oxidative stress is a condition where the level of toxic ROS exceeds the antioxidant defense in the body (Syahrizal, 2008). This results in an excess of free radicals reacting with fat, protein, and cellular nucleic acid, causing local damage and specific organ dysfunction. The body produces antioxidant enzymes SOD, catalase and glutathione, but it was not sufficient to neutralize free radicals 
swarming in mass in the body. These free radicals can be suppressed by administration of natural antioxidants (Halliwell, 2007).

Curcuma (Curcuma Xanthorrhiza Roxb.) is a medicinal plant of Zingiberaceae family that is widely grown and used as a traditional medicine in Indonesia (Sidik et al, 1992; Prana, 2008). Examination on the efficacy of curcuma rhizome can be found out through empirical evidence, in vitro tests, pre-clinical testing on animals, and clinical trials on humans (BPOM, 2004). Empirically curcuma rhizome is known to have many benefits; one of which is its potential as antioxidant (WHO, 1999). The active components acting as antioxidants in curcuma rhizome are curcumin, demethoxycurcumin, and bisdemethoxycurcumin (Masuda, 1992). Research conducted by Jitoe et al (1992) showed that the antioxidant activity of curcuma extract was greater than the activity of three types of curcuminoid believed to be contained in curcuma. Therefore, it is suspected that there is another substance from the three curcuminoids which has antioxidant effect in curcuma extract. Similarly, research by Rao (1995) showed that curcumin is more active than vitamin $\mathrm{E}$ and beta-carotene. This is because the role of curcumin as an antioxidant counteracting free radicals cannot be separated from the structure of curcumin compound. Curcumin has an important group in the antioxidant process. Curcumin structure consists of phenolic hydroxyl and beta diketone group. Phenolic hydroxyl group serves its function by catching of free radicals on the first phase of antioxidative mechanism. Compound structure of curcumin has two phenolic groups, so that one curcumin molecule can ward off two free radicals. Beta diketone group serves the same function, but in the next phase.

The increasing use of MSG in long term surely brings negative effects that cause oxidative stress. In addition, it has been proven that MSG can also affect the performance of reproductive system hormones, such as estrogen which plays an important role in the elasticity of vaginal walls and the proliferation of vaginal epithelial cells. Based on these descriptions, a research is conducted on the effects of curcuma (Curcuma xanthorrhiza Roxb.) rhizome extract in preventing the decrease of vaginal epithelium thickness in mice exposed to MSG.

\section{MATERIALS AND METHODS}

The study uses the design of true experimental posttest only control group. Experimental animal used in the study are female Mus Musculus mice. Intervention conducted are that of mice (Mus Musculus) that have met inclusion and exclusion criteria are given exposure to MSG and the treatment group was given extracts of curcuma rhizome (Curcuma Xanthorrhiza Roxb.) with three different doses. Not until the treatment had been given was the measurement of the vaginal epithelium thickness taken. This study investigates the effect of various doses of curcuma rhizome extract on vaginal epithelium thickness in mice exposed to MSG.

\section{Tools And Materials}

The instruments used in the experiment include: (1) Equipment for extracting curcuma rhizome using maceration: Oven, blender, scales, Erlenmeyer glass, funnel glass, filter paper, ethanol container, evaporator, cooling spiral/rotary evaporator, water pump hose, water pump, water bath, vacuum pump, flask for the final extract; (2) Surgical Equipment include: surgical scissors, tweezers, surgical board, glass beaker, cotton, betadine, scalpels; (3) Equipment for HE staining include: Tissue text processor, paraffin, paraffin oven, xylol solution flask, alcohol tube, Petri dish, flask, bottles, pipette, measuring cups, funnel cups, knives, timer, goblets, small boxes, wooden holder, spatula, refrigerator, rotary microtome and the knife, small brush, object glass, glass caps, hot plate, staining jar, glass shelf, plastic containers, 
capillary pipe, blotting paper, tissue paper and preparation box, incubation container, Olympus microscope.

Materials used include: (1) materials for extracting curcuma rhizome by maceration include: ginger rhizome, $70 \%$ ethanol, distilled water; (2) the material used for the surgery include: chloroform solution; (3) HE staining materials include: preparations of mice's vagina based on treatment group, major paint (Harris Hematoxylin), 1\% alcohol, ammonia, paint comparator (eosin).

\section{Research Sample}

This study is conducted using 25 mice (Mus musculus) with the following criteria: age of 1-2 months, body weight of 18-35 gram, healthy and do not show any anatomical disability, and female.

\section{Experimental Animal Treatment}

Experimental animals were randomly divided into 5 groups. Five mice were put in a control group 1 (K1) treated with CMC-Na only; another 5 were in control group 2 (K2) and treated with MSG; and the rest of 15 mice were divided into three treatment groups as follows: MSG + curcuma rhizome extract with dose $1(0.4 \mathrm{mg} / \mathrm{gr} \mathrm{BW})$ for group 1 , MSG + curcuma rhizome extract with dose $2(0.8 \mathrm{mg} / \mathrm{gr} \mathrm{BW})$ for group 2, and MSG + curcuma rhizome extract with dose $3(1,2 \mathrm{mg} / \mathrm{gr} \mathrm{BW})$ for group 3 . The treatment was conducted for 42 days. On day 43, surgery was performed after ensuring that the mice were in proestrus phase characterized by the presence of vaginal epithelial cell with nuclei post vaginal examinations. The vagina of each mouse was taken and sent to pathology laboratory in Public Hospital to be prepared for histology and Hematoxillin-eosin staining. The thickness of vaginal epithelium was observed and each replication was measured under 40x magnification of micrograph Olympus microscope at ten points which were then summed and averaged to get the final result of vaginal epithelium thickness.

\section{Data Analysis}

The data obtained weere then tested for normality and homogeneity using Kolmogorov-Smirnov and Lavene test. From both testing, it was found out that all the data were normally distributed and homogeneous, meeting the requirements for performing parametric test. To determine the effect of curcuma rhizome extract on the thickness of vaginal epithelium, a one way ANOVA test was conducted and data were analyzed using SPSS 20 for windows.

\section{RESULT AND DISCUSSION}

Preparations of vaginal tissues were cut transversely and measurement of the vaginal epithelium thickness in mice was performed on slides that had been through the process of histopathological preparations and hematoxylin eosin staining. Data collection was done by microscopic observation using Olympus Dot Slide XC 10 to 25 histological preparation vaginas under 40x magnification. Measurement techniques were divided into 4 quadrants and measured with 10 points. Figure of observation result and measurement of vaginal epithelium thickness in each treatment group after exposed to MSG is shown in Figure 1. 

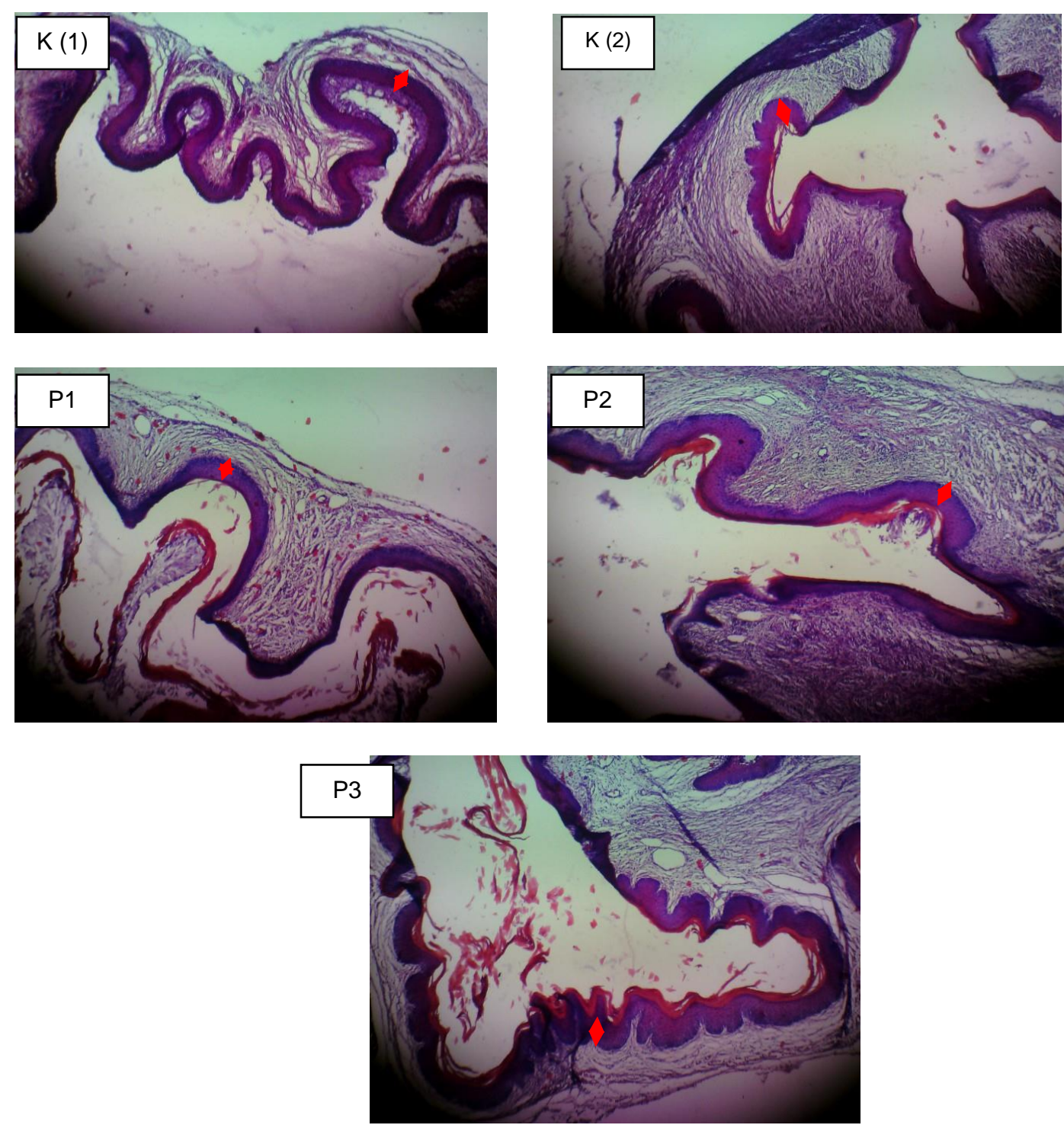

Figure 1. Measurement of vaginal epithelium thickness in mice using Dot Slide Olympus XC 10 digital camera under 40x magnification in each treatment group.

The results of measurements on vaginal epithelial thickness of mice on a microscopic preparations can be seen in Table 1 .

Table 1. Comparison of Measurement Results on Vaginal Epithelial Thickness in Mice (Mus musculus) That Were Exposed to MSG on Each Treatment Group.

\begin{tabular}{cccccc}
\hline Group & \multicolumn{5}{c}{ Vaginal Epithelial Thickness $(\mu \mathrm{m})$ in repetition order: } \\
& 1 & 2 & 3 & 4 & 5 \\
K1 & 80.2 & 119.85 & 133.05 & 174.95 & 147.9 \\
K2 & 154.05 & 111.85 & 114.8 & 81.55 & 77.05 \\
P1 & 125.95 & 111.95 & 101.2 & 102.2 & 128.55 \\
P2 & 84.05 & 107.15 & 94.85 & 140.7 & 130.4 \\
P3 & 121.7 & 139.2 & 147.8 & 153.75 & 114.3 \\
\hline
\end{tabular}


Having obtained the results of the measurement and normality and homogeneity test of the data, it is obtained that $\rho$-value $>0.05$, so it can be inferred that data are distributed normally and homogeneity of data variance has been met and parametric tests using One Way ANOVA can be commenced. Here are the results of the experiment on the effect of administering curcuma rhizome extract (Curcuma xanthorrhiza Roxb.) at varying doses on the thickness of vaginal epithelium using ANOVA.

Table 2. Effect of Administering Curcuma Rhizome Extract (Curcuma Xanthorrhiza Roxb.) at Various Doses on the Thickness of Mice's Vagina Epithelium

\begin{tabular}{ccc}
\hline Curcuma Rhizome Extract & Mean \pm SD & p-value \\
& & \\
K 1 & $131.19 \pm 35.09$ & 0.341 \\
K 2 & $107.90 \pm 31.06$ & \\
P1 & $113.97 \pm 12.86$ & \\
P2 & $111.43 \pm 23.77$ & \\
P3 & $135.35 \pm 16.87$ & \\
\hline
\end{tabular}

Based on the analysis above, p-value of 0.341 was obtained; in which it was greater than $\alpha=0.05$, so that it can be concluded from the test results that administering extract of curcuma rhizome (Curcuma Xanthorrhiza Roxb.) at various doses did not significantly affect the thickness of vaginal epithelium in mice exposed to MSG.

The results of the study indicate that there is no significant effect of administering curcuma rhizome extract on the thickness of vaginal epithelium in mice that are exposed to MSG. This is supported by the results of analysis using ANOVA, with a p-value of 0.341 . From the research results, data is obtained that the average thickness of vaginal epithelium in the negative control groups that were not given MSG is higher than that in the positive control groups that were given MSG orally. These results are consistent with studies that had been conducted by Wahyuni et al (2014) that the administration of MSG in female mice can inhibit the ER- $\alpha$ in the endometrium of the uterus. This is also reinforced by evidence that there is a thinning in the endometrium of mice given MSG orally. In addition, the location of the estrogen receptor $\alpha(E R-\alpha)$ can also be found in vagina, making it possible that thinning in vaginal epithelial wall is also caused by oral administration of MSG.

Glutamate is a neurotransmitter essential for communication inter-neurons. Consumption of monosodium glutamate (MSG) in excessive doses can increase glutamate in plasma and chemically might induce free radicals, in which glutamate receptors work more actively and so excitotoxins happens. With this condition, glutamate signaling pathway that is required by the body to form amino acids and neurotransmitters become damaged. Large amounts of free radicals in the body will affect the function of organs of the body, especially the hypothalamus. Hypothalamic function in producing GnRH, FSH and LH deteriorates, and it results in the imbalance of estrogen and progesterone levels that is instrumental in reproductive cycle. Estrogen will be secreted properly if feedback on hypothalamus is not obstructed by the presence of free radicals (Umami., Et al, 2014).

Estrogen deficiency will result in the decrease of epithelial proliferation and maturation of epithelium becomes intermediate and superficial cells. This happens because all layers disappear except basal cell layer. The epithelium of the vagina becomes pale and very thin and thus susceptible to infections and inflammatory processes in submucosal tissue, causing local irritation and tendency to bleeding. Other effects of the thinning of vaginal epithelium are the decrease of blood flow to the vagina, deterioration in vaginal elasticity, burned 
sensation in vaginal area, itchiness and dryness. Therefore, to prevent the thinning of vaginal epithelium caused by excessive consumption of MSG, antioxidant that can ward off free radicals in the body is extremely needed.

Several studies have shown that curcuma rhizome extract has antioxidant content. Rosidi, et al (2014) in his research analyzing the potential of curcuma as an antioxidant concluded that rhizome extract of this particular plant has antioxidant activity amounted to $87.01 \mathrm{ppm}$ which is classified as active and potential as a good natural antioxidant. The active components serving as antioxidants in the extract of curcuma rhizome are curcumin, demethoxycurcumin, and bisdemethoxycurcumin (Masuda, 1992). Curcumin found in curcuma is a natural antioxidant, where its activity is greater than $\alpha$-tocopherol (vitamin $\mathrm{E}$ ) when tested in oil (Wahyudi, 2006). Curcumin has phenolic hydroxyl groups and betadiketone group which are essential in antioxidant process. Phenolic compounds contained in phenolic hydroxy group serves as an antioxidant because of its ability to counteract free radicals and peroxide radicals, and therefore it proves to be effective in inhibiting oxidation of lipids (Kinsella et al, 1993). Thus, phenolic hydroxyl group serves as a catcher of free radicals on the first phase of anti-oxidative mechanism while beta-diketone group serves the same function on the next phase (Rao, 1995).

Tay et al., (1997) in her study of the effects of antioxidants in mice exposed to MSG mentioned that giving antioxidants can stimulate secretory epithelial cells in mice's fallopian tubes. In addition, administration of antioxidants would also stimulate gonadotropin secretion (LH and FSH) from the anterior pituitary, thus increasing estrogen levels in reproductive organs, including the vagina. Studies on the effects of antioxidants on the thickness of epithelial cells have also been carried out by Umami, et al., (2014) who concluded that the antioxidant content in vitamins $\mathrm{C}$ and $\mathrm{E}$ in administered to mice that were exposed to MSG can ward hydroxyl radicals $(\mathrm{OH})$ in the fallopian tubes which increased the number of secretory epithelial cells and thick layer of smooth muscle. The higher the dosage given, the greater are the effects on increasing the number of secretory epithelial cells in mice's fallopian tubes.

The results of research by Rosidi, et al (2014) regarding the potential of ginger as an antioxidant concluded that antioxidant activity of curcuma rhizome extract is not as good as vitamin C value: IC50 of $87.01 \mathrm{ppm}$ in curcuma rhizome extract compared to $1.47 \mathrm{ppm}$ in vitamin $\mathrm{C}$. The lower $\mathrm{IC}_{50}$ value of a material is, the higher is the antioxidant activity. These are consistent with the results of this study in which there is no significant impact of administering various doses of curcuma rhizome extract as bioactive compound producer on the thickness of vaginal epithelium in mice exposed to MSG. Nevertheless, the data obtained in this study shows that the average thickness of vaginal epithelium in P3 group (group treated by administration of MSG + curcuma extract of $1,2 \mathrm{mg} / \mathrm{gr}$ BW) has the highest thickness even when compared with $\mathrm{K} 1$ group that did not receive oral administration of MSG. From the result, it can be assumed that administering curcuma rhizome extract at a dose of $1.2 \mathrm{mg} / \mathrm{gr} \mathrm{BW}$ has an effect on the increase of vaginal epithelium thickness in mice exposed to MSG although the effect is not statistically significant.

\section{CONCLUSION}

Administering extract of curcuma (Curcuma Xanthorrhiza Roxb.) rhizome in various doses does not significantly affect the increase in the thickness of vaginal epithelium in mice (Mus musculus) that are exposed to MSG.

\section{REFERENCES}

[1] Depkes RI. 2008. Riset Kesehatan Dasar (Riskesdas) 2007. Jakarta: Badan Penelitian dan Pengembangan Kesehatan Departemen Kesehatan, Republik Indonesia. 
[2] Farombi EO., Onyema OO. 2006. Monosodium glutamate-induced oxidative damage and genotoxicity in the rat: modulatory role of vitamin $\mathrm{C}$, vitamin $\mathrm{E}$ and quercetin. Human \& Experimental Toxicology, 5(25), p. 251-259.

[3] Giacometti T. 1979. Free And Bound Glutamate In Natural Products. In: Glutamic Acid:Advances In Biochemistry (Filer, L.J., Garattini, S., Kare, M.R., Reynolds, W.A. and Wurtman, R.J., eds). New York: Raven Press. p. 25 - 34.

[4] Halliwell, B., 2007. Free Radicals in Biology and Medicine. Fourth edition. Oxford University Press. Chapter 2 and chapter 3, p.42-72.

[5] Kinsella, J.E., Frankel, E., German, B. and Kanmer, J., 1993. Possible mekanisme for the protective role of antioxidants in wine and plant foods. J Food Technology. Vol. 4, p. 5-89.

[6] Masuda T., Isobe J., Jitoe A., Naktani., Nobuji. 1992. Antioxidative curcuminoids from rhizomes of Curcuma xanthorrhiza. Phytochemistry, 31(10): 3645-3647.

[7] Megawati D., Sutarno., Listyawati S. 2005. Siklus estrus dan struktur histologi ovarium tikus putih (rattus novergicus 1 ) setelah pemberian monosodium glutamat (msg) secara oral. J. Biosmart, 7 (1): 47-52.

[8] Prana, MS. 2008. The biologi of temulawak (Curcuma xanthorrhiza Roxb.). Bogor (ID) : Biopharmaca Research Center Bogor Agricultural University. Hal. 151-156.

[9] Rao, MNA. 1995. Antioxidant properties of curcumin. International symposium on curcimin phannacochemistry (ISCP) Yogyakarta (ID) : Fakultas Farmasi Universitas Gajah Mada bekerjasama dengan The Departement of Pharmacochemistry Vrije Universiteit Amsterdam.

[10] Rosidi, A., Khomsan, A., Setiawan, B., Riyadi, H., Briawan, D. 2014. Potensi Temulawak (Curcuma xanthorrhiza Roxb) Sebagai Antioksidan. Prosiding Seminar Nasional Hasil-hasil Penelitian dan Pengabdian

[11] Septadina, Indri Seta. 2014. Pengaruh Monosodium Glutamat Terhadap Sistem Reproduksi. Seminar Bagian Anatomi. Fakultas Kedokteran Universitas Sriwijaya.

[12] Sidik., Mulyono MW., Muhtadi A. 1992. Temulawak (Curcuma xanthorrhiza Roxb). Jakarta (ID): Yayasan Pengembangan Obat Bahan Alam Phytomedica.

[13] Stehle P. 2007. Consensus meeting:monosodium glutamate-an update. European Journal of Clinical Nutrition, 61:304-313.

[14] Sutarno., Megawati D., Listyawati S. 2005. Estrous cycle and histologic structure of rat's (Rattus norvegicus L.) ovaries by oral administration of monosodium glutamate. $J$ Biosmart, 7(1)47-52.

[15] Tay, JI., Rutherfor., Killick., Maguines, SD., Patridge., and Leese HJ. 1997. Human tubal fluid: production, nutrient composition and response to adrenergic agents. Human Reproduction, Vol. 12(11), p. 2451-2456.

[16] Trentini, botticelli A. 1990. Effect of Monosidium Glutamate on The endrocine Glands, and Reproductive Function of The Rat, Fert. Steril, 25, : 478-483.

[17] Umami, Riza., Made, Pande., Winarsih, Sri. 2014. Pengaruh vitamin C dan E terhadap histology tuba fallopii pada tikus yang dipapar MSG. Jurnal Kedokteran Brawijaya, vol. 28(2), p. 63-67.

[18] Wahyuni, E.D., Situmorang, C.C., Dwijayasa, P.M. 2014. Combination of vitamin C and $\mathrm{E}$ modulated monosodium glutamate-induced endometrial toxicily in female wistar rats, Asian Pacific Journal of Reproduction, vol. 3(2), p. 106-109.

[19] Walker ., Lupien . 2000. The safety evaluation of monosodium glutamate. Journal of Nutrition, 130:1049-1052.

[20] World Health Organization (WHO). 1999. Monograph on selected medicinal plant. Vol 1. Jenewa: WHO. 